\title{
Universal TA Cloning
}

\author{
Ming-Yi Zhou and Celso E. Gomez-Sanchez* \\ Endocrinology, The University of Mississippi \\ Medical Center, 2500 North State Street, \\ Jackson, MS 39216, USA \\ G.V. (Sonny) Montgomery VA Medical Center, Jackson, \\ MS and The University of Missouri-Columbia, MO USA
}

\section{Abstract}

TA cloning is one of the simplest and most efficient methods for the cloning of PCR products. The procedure exploits the terminal transferase activity of certain thermophilic DNA polymerases, including Thermus aquaticus (Taq) polymerase. Taq polymerase has non-template dependent activity which preferentially adds a single adenosine to the 3 '-ends of a double stranded DNA molecule, and thus most of the molecules PCR amplified by Taq polymerase possess single 3'-A overhangs. The use of a linearized "T-vector" which has single 3'-T overhangs on both ends allows direct, high-efficiency cloning of PCR products, facilitated by complementarity between the PCR product 3'-A overhangs and vector 3'-T overhangs. The TA cloning method can be easily modified so that the same T-vector can be used to clone any double-stranded DNA fragment, including PCR products amplified by any DNA polymerase, as well as all blunt- and sticky-ended DNA species. This technique is especially useful when compatible restriction sites are not available for the subcloning of DNA fragments from one vector to another. Directional cloning is made possible by appropriate hemi-phosphorylation of both the T-vectors and the inserts. With a single T-vector at hand, any DNA fragment can be cloned without compromising the cloning efficiency. The universal TA cloning method is thus both convenient and labor-saving.

\section{Introduction}

The cloning of a DNA fragment into a plasmid vector is a routine procedure in recombinant DNA technology. Cloning methods can be divided into two classes, depending on whether or not ligase is required. The most common method for cloning and subcloning requires the use of DNA ligase to covalently link the compatible ends of the DNA fragment and the linearized plasmid, forming a single cyclic molecule that is capable of autonomous replication in host cells $(1,2)$. Recently, ligation-independent or ligase-free cloning methods have been developed for the cloning of polymerase chain reaction (PCR) amplified DNA fragments. These ligation-independent methods involve the generation of long (10-12 bases) protruding 3'-ends on PCR amplified DNA fragments which are annealed specifically to complementary DNA sequences of an appropriate plasmid vector, and the annealed products are subsequently transformed directly into competent cells. The application of the ligase-free procedure is limited by its requirement for extra-long primer synthesis and enzymatic modification steps (3-6).

There are two subclasses of ligase-dependent methods employed for the covalent joining of a DNA insert to a plasmid vector. One approach is cohesive-end ligation, in which cohesive ends on the insert and plasmid are generated by digestion with appropriate restriction enzymes, and the complementary ends of the plasmid and insert are then joined by DNA ligase. This approach is the most efficient of the two. However, for every restriction fragment having distinct cohesive ends, one linearized plasmid vector compatible with that (those) particular restriction site(s) has to be prepared. The other, less efficient approach is blunt-end ligation in which blunt-ended DNA fragments are ligated to a linearized blunt-ended plasmid. Both of the ligase-dependent methods require multiple purification and/or enzymatic modification steps.

Although the development of PCR made the rapid amplification of DNA fragments generally quite simple, the cloning of PCR products was often found to be quite difficult using early technology. Several methods have now been developed for the cloning of PCR-amplified DNA molecules, including cohesive-end cloning by the introduction of restriction sites at the 5 '-ends of PCR primers (7), bluntend cloning $(8,9)$, ligation-independent cloning (3-6), and TA cloning $(10,11,12)$. It has been observed that many DNA polymerases, including Thermus aquaticus (Taq) DNA polymerase, are capable of adding an additional nontemplate directed nucleotide to the 3'-ends of a blunt-ended DNA fragment. Taq polymerase preferentially adds a single $3^{\prime}$-A to blunt-ended, double-stranded DNA via this terminal transferase-like activity $(13,14)$. Most of the PCR products amplified by Taq polymerase thus possess a single $3^{\prime}-A$ overhang at both ends. To directly clone PCR products which have 3'-A overhangs, one can use a linearized " $T$ vector" which has a 3 '-T overhang at each end $(10,11$, 12). The complementarity between the vector 3 '-T overhangs and PCR product 3'-A overhangs allows direct ligation of Taq-amplified PCR products into the T-vector, and this strategy is commonly referred to as "TA cloning." The TA cloning strategy is both simple and much more efficient than blunt-ended ligation for the cloning of PCR products.

With minor modifications, the TA cloning method, originally designed to facilitate the cloning of PCR products, is easily converted to a universal cloning method (15). All DNA fragments, with the exception of those with protruding 3 '-ends, are directly converted to double stranded DNA molecules having 3'-A overhangs by incubation with Taq polymerase in the presence of the four dNTPs. These modified inserts are then ligated to T-vectors. In the case of DNA fragments having protruding 3 '-ends, the DNA fragments are first made blunt by incubation with T4 DNA polymerase, and are then treated with Taq polymerase, as described above (Figure 1). A cloning efficiency of up to $90 \%$ is routinely achieved. The universal TA cloning technique is especially useful when compatible restriction sites are not available for subcloning DNA fragments from 


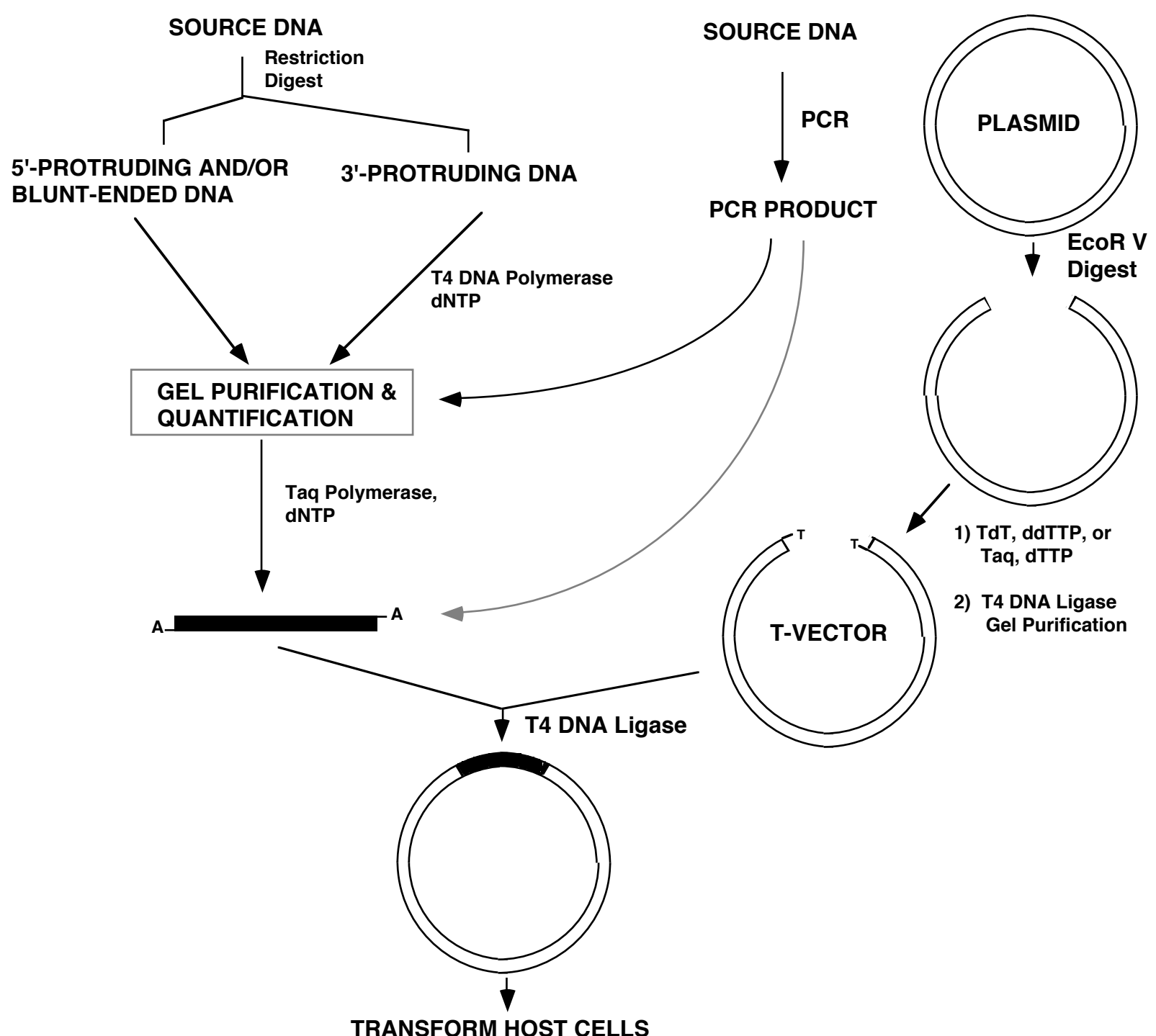

Figure 1. Schematic diagram outlining the cloning procedures using universal T-vectors (see text for details).

one vector into another. Directional cloning is made possible by the appropriate hemi-phosphorylation of both the T-vectors and the inserts. Thus, with a single T-vector at hand, any DNA fragment can be cloned without compromising the cloning efficiency. The universal TA cloning method is a convenient and labour-saving alternative to traditional, restriction endonuclease-mediated cloning strategies.

\section{Protocols}

\section{Materials}

dNTPs and ddTTP (United States Biochemical), high and low melting temperature agaroses (Fisher Scientific). Taq DNA polymerase (Promega), Terminal deoxynucleotidyltransferase (Boehringer Mannheim), T4 DNA ligase
(Promega), T4 DNA polymerase and Restriction enzymes (New England Biolabs). Appropriate buffers are provided or specified by the suppliers. Wizard DNA clean-up Kit, Wizard PCR Preps Kit and Wizard Minipreps DNA Purification Kit (Promega). One Shot or Ultracomp Top10F' (Invitrogen). pBluescript (Stratagene), pcDNA3 (Invitrogen).

\section{Protocol 1: T-Vector Preparation}

You may choose any plasmid which satisfies your needs as long as the plasmid contains a unique blunt-end restriction site in the multiple cloning sites polylinker (for example, the EcoR V site of the pBluescript plasmid, which has blue/white color selection, may be used for cloning). For expression in eukaryotic cells the pcDNA3 plasmid can be used. The T-vectors are prepared in batch and stored as aliquots at $-20^{\circ} \mathrm{C}$ for future use. 
Digest Plasmids with Blunt-End Restriction Enzyme

1. In a $1.5 \mathrm{ml}$ microcentrifuge tube, add:

$\begin{array}{ll}\text { plasmid DNA } & 10 \mu \mathrm{g} \\ 10 X \text { EcoR V buffer } & 5 \mu \mathrm{l} \\ \text { EcoR V } & 50 \text { units } \\ \text { water to final total volume of } & 50 \mu \mathrm{l}\end{array}$

Mix by gentle vortex and centrifuge briefly.

2. Incubate at $37^{\circ} \mathrm{C}$ for $1-2 \mathrm{~h}$.

3. After $1 \mathrm{~h}$ of digestion, $1-2 \mu \mathrm{l}$ of mix are taken and run on a $1 \%$ agarose gel to make sure the digestion is complete.

4. Add $2 \mu \mathrm{l}$ of $0.5 \mathrm{M}$ EDTA to the tube at the end of digestion.

\section{Purification of Blunt-Ended Plasmid DNA}

We routinely use the Wizard DNA Clean-up System to purify DNA, and the major steps are listed below. When using the Wizard DNA Clean-up kit, it is important to elute the DNA from the resin with water. EDTA in the TE buffer will chelate $\mathrm{Mg}^{++}$, thus reducing the working concentration of $\mathrm{Mg}^{++}$in the next enzyme incubation step. The phenol/ chloroform extraction and ethanol precipitation method also works well.

1. Add $1 \mathrm{ml}$ of well mixed Wizard DNA Clean-up resin to the tube containing the enzyme digestion products, and mix by inverting for $1 \mathrm{~min}$.

2. Attach a $3 \mathrm{ml}$ disposable syringe barrel (without the plunger) to the minicolumn provided, and insert the tip of the minicolumn/syringe barrel assembly into a vacuum manifold.

3. Pipet the DNA/resin mix into the syringe barrel. Apply the vacuum to draw the mix into the minicolumn.

4. Pipet $2 \mathrm{ml}$ of $80 \%$ isopropanol into the syringe barrel, and apply the vacuum to draw the solution through the minicolumn.

5. Remove the syringe barrel and transfer the minicolumn to a $1.5 \mathrm{ml}$ centrifuge tube. Centrifuge the minicolumn for 2 min at $12,000 \times \mathrm{g}$.

6. Attach the minicolumn to the vacuum source, and apply the vacuum for another 2 min.

7. Transfer the minicolumn to a new $1.5 \mathrm{ml}$ microcentrifuge tube, add $50 \mu$ l of water (pre-warmed to $65^{\circ} \mathrm{C}$ ) to the minicolumn, and wait for $1 \mathrm{~min}$. Centrifuge the minicolumn for $20 \mathrm{~s}$ at $12,000 \mathrm{xg}$. The DNA is collected in the microcentrifuge tube.

Addition of T-overhangs to the Blunt-ended Plasmid Vector Two widely used methods are described. The first method employs terminal deoxynucleotidyl-transferase (TdT) and dideoxythymidine triphosphate (ddTTP) to add a ddT residue to the blunt-ended plasmid, which ensures the addition of only a single $\mathrm{T}$ residue (10). In the second method, Taq polymerase and dTTP are used to add a 3'-T to the blunt-ended plasmid (11). Since Taq polymerase adds the 3 '-T residues inefficiently, only a portion of the blunt-ended plasmids are T-tailed at both ends, whereas the remainder are T-Tailed only at one end or do not have T-tails at all. Therefore, the vectors without T-overhangs are eliminated from the T-vectors by gel purification after self-ligation and/or concatemerization by incubation with T4 DNA ligase (16 ). Unlike Taq polymerase, terminal transferase adds ddT to 3 '-ends very efficiently. Therefore consistent and high cloning efficiency is obtained using Tvectors prepared by $\mathrm{TdT}$, even without ligation and gel purification steps. However, the efficiency can be further increased by incubation with T4 DNA ligase, followed by gel separation.

\section{A. Terminal Transferase Method}

This method originated from Holton and Graham (10), with minor modifications in our laboratory. Terminal transferase from Boehringer Mannheim is strongly recommended. TdT from other sources may not work as well. The final concentration of ddTTP in the reaction is $20 \mu \mathrm{M}$; higher concentrations are unnecessary.

1. Pipet $46 \mu$ l of purified blunt-ended plasmid DNA (from step 7 of "Purification of Blunt-ended Plasmid DNA") into a $1.5 \mathrm{ml}$ centrifuge tube (if the volume is less, add sterile water to bring the volume to $46 \mu \mathrm{l}$ ), then mix the following reagents:

$\begin{array}{ll}\text { purified Blunted plasmid DNA } & 46 \mu \mathrm{l} \\ 5 \mathrm{X} \mathrm{TdT} \text { buffer } & 15 \mu \mathrm{l} \\ 25 \mathrm{mM} \mathrm{CoCl}_{2} & 7.5 \mu \mathrm{l} \\ 1 \mathrm{mM} \mathrm{ddTTP} & 1.5 \mu \mathrm{l} \\ \text { Terminal Transferase }(25 \mathrm{U} / \mu \mathrm{l}) & 5 \mu \mathrm{l}\end{array}$

Mix by gentle vortexing and centrifuge briefly.

2. Incubate at $37^{\circ} \mathrm{C}$ for $1.5 \mathrm{~h}$, then proceed to the "Purification of the T-tailed Vectors" (see below).

B. Taq Polymerase Method

1. Adjust the volume of the purified blunted plasmid DNA (from step 7 of "Purification of Blunt-ended Plasmid $D N A$ ") to $83 \mu$ l by adding sterile water, then mix the following reagents:

$\begin{array}{ll}\text { Purified blunted plasmid DNA } & 83 \mu \mathrm{l} \\ 10 \times \mathrm{PCR}_{\text {buffer }\left(\mathrm{MgCl}_{2} \text { free }\right)} & 10 \mu \mathrm{l} \\ 50 \mathrm{mM} \mathrm{MgCl}_{2} & 5 \mu \mathrm{l} \\ 100 \mathrm{mM} \mathrm{dTTP} & 1 \mu \mathrm{l} \\ \text { Taq polymerase }(5 \mathrm{U} / \mu \mathrm{l}) & 1 \mu \mathrm{l}\end{array}$

Mix well and centrifuge briefly.

2. Incubate at $72^{\circ} \mathrm{C}$ for $2 \mathrm{~h}$, then proceed to the "Purification of the T-tailed Vectors" (see below).

\section{Purification of the T-tailed Vectors}

The T-tailed plasmid DNA solution obtained by any one of the methods described above is purified by employing the Wizard DNA Clean-up System as described above or phenol/chloroform extraction and ethanol precipitation.

\section{Ligation of Vectors without T-tails}

If you use the Taq polymerase method to make the Tvectors, removal of the vectors without T-tails is necessary and improves the cloning efficiency up to $80 \%$ (16). If the terminal transferase method and a plasmid without blue/ white selection (for example pcDNA3) is used to make Tvectors, the cloning efficiency is about $70 \%$, without further purification. Elimination of the vectors without T-overhangs by gel separation, following incubation with T4 DNA ligase, increases the cloning efficiency to $90 \%$. If you use the terminal transferase method to make T-vectors, and the plasmid has blue/white selection capabilities, ligation and gel purification may not be necessary (Go directly to "Quantification and Storage of the Purified T-vector" below if time savings is desired).

1. To a $1.5 \mathrm{ml}$ microcentrifuge tube, add
T-tailed plasmid DNA (as purified above)
10x ligase buffer
T4 DNA ligase (3 $\mathrm{U} / \mu \mathrm{l})$ 

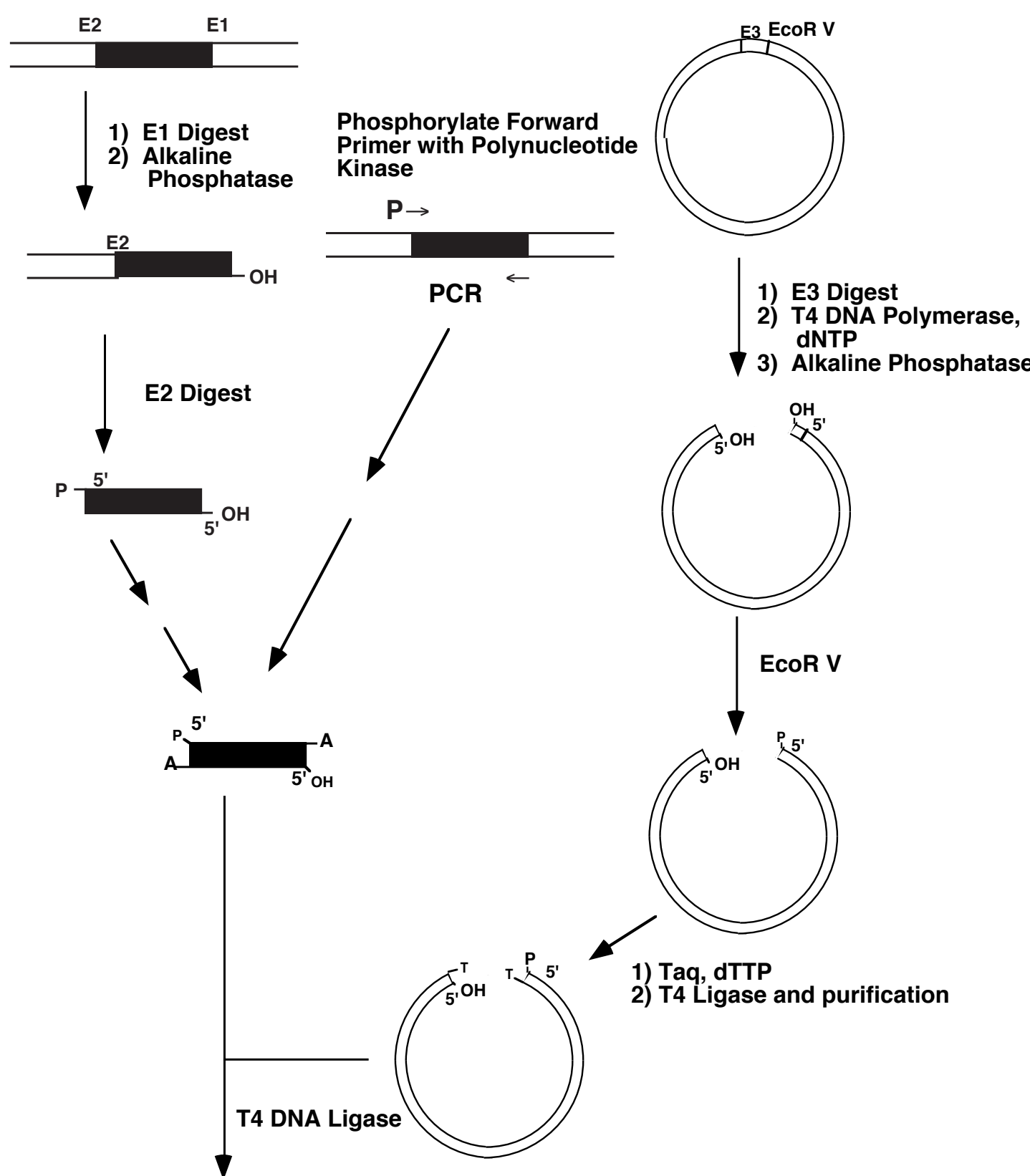

3) Alkaline Phosphatase

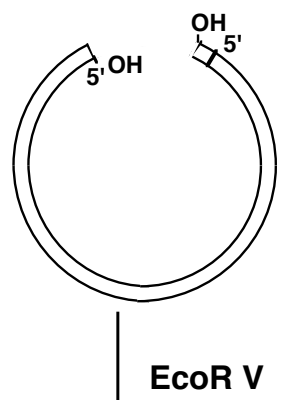

1) Taq, dTTP

2) T4 Ligase and purification

\section{Transform host cells}

Figure 2. Schematic diagram demonstrating the strategies for directional TA cloning. E1, E2 and E3 are restriction enzymes. When E3 is an enzyme which generates blunt ends, the incubation step with T4 DNA polymerase and dNTP is not necessary. 
Mix well and centrifuge briefly.

2. Incubate at $16^{\circ} \mathrm{C}$ overnight.

Separation and Recovery of T-vectors on an Agarose Gel $\mathrm{T}$-vectors are separated from the self-ligated and concatemerized plasmid DNA on a $1 \%$ agarose gel. The T-vector band is cut out and recovered using the Wizard PCR Preps Kit.

1. Separate the ligation mixture (from above) on a $1 \%$ low-melting agarose gel with $0.5 \mu \mathrm{g} / \mathrm{ml}$ of ethidium bromide. Run the gel in TAE buffer at 5 volts $/ \mathrm{cm}$.

2. Visualize the DNA bands with a hand-held long wave (365 nm) UV light. Excise the T-vector band with a sterile scalpel. Transfer the gel slice to a $2 \mathrm{ml}$ microcentrifuge tube.

3. Incubate the gel slice in a $65^{\circ} \mathrm{C}$ water bath for $5 \mathrm{~min}$, or until melted.

4. Add $1 \mathrm{ml}$ of Wizard PCR preparation resin (which has been thoroughly mixed) to the melted agarose slice. Mix thoroughly by inverting for $1 \mathrm{~min}$.

5. Follow steps 2 to 7 of the "Purification of Blunt-Ended Plasmid DNA" to complete the purification.

Quantification and Storage of the Purified T-vector The concentration of the purified T-vector or other DNA can be conveniently estimated by running an aliquot of the DNA side by side with a known amount of a DNA standard in a $1 \%$ agarose gel, and then comparing the relative brightnesses of the bands. The electrophoresis is run at a higher than normal voltage for a short time (usually 10-15 $\mathrm{min}$ ) to allow the DNA to more efficiently migrate into the gel. Standard loading buffer contains bromphenol blue and xylene cyanol which may interfere with the visualization of band brightness. Therefore, it is strongly suggested that a $6 \mathrm{X}$ loading buffer without these dyes be used for quantification purposes. The T-vectors are aliquoted and stored at $-20^{\circ} \mathrm{C}$ to reduce multiple freeze-thaw cycles.

1. Run $1 \mu \mathrm{l}$ of the purified T-vector and a known amount of standard DNA side by side (use loading buffer without any dyes) in a $1 \%$ agarose gel at 10 volts/cm for $10-15$ $\min$.

2. Compare the band brightnesses to determine the concentration of the T-vector.

3. Aliquot the T-vector to several tubes and store them at $-20^{\circ} \mathrm{C}$.

\section{Protocol 2: TA Cloning Procedure}

Preparation of Source DNA

A. DNA Fragments from Restriction Enzyme Digest

Usually two restriction enzymes are needed to release the insert DNA. It is frequently possible to choose a buffer in which the two enzymes will remain active, and therefore the two enzyme digestions can be carried out simultaneously. The protocol described below gives an example of two digestions performed in the same buffer. In cases of either buffer or temperature incompatibility, separate digestions may be required. The reader is advised to refer to some basic manuals (1). If the insert has one or two 3'-overhangs, they must be removed with T4 DNA polymerase.
1. In a $1.5 \mathrm{ml}$ microcentrifuge tube, add:

$\begin{array}{ll}\text { DNA } & 5 \mu \mathrm{g} \\ 10 \times \text { buffer } & 4 \mu \mathrm{l} \\ \text { Enzyme 1 } & 20 \text { Units } \\ \text { Enzyme 2 } & 20 \text { Units }\end{array}$

sterile water to final total volume of $40 \mu \mathrm{l}$

Mix well and centrifuge briefly.

2. Incubate at the recommended temperature (usually $37^{\circ} \mathrm{C}$ ) for $1-2 \mathrm{~h}$. If the enzymes produce inserts with $5^{\prime}$-overhangs or blunt-ends, proceed to the gel purification step. If inserts have 3 '-overhang(s), continue with steps 3 to 5 .

3. Steps 3 to 5 are only for the enzymes which produce insert DNAs with 3'-overhangs. Put the above digestion solution on ice, and add: dNTP mix, $10 \mathrm{mM}$ each $\quad 0.5 \mu \mathrm{l}$ T4 DNA polymerase 6 Units

Mix well and centrifuge briefly.

4. Incubate at $11^{\circ} \mathrm{C}$ for $20 \mathrm{~min}$.

5. Add $2 \mu \mathrm{l}$ of $0.5 \mathrm{M}$ EDTA to stop the reaction. Then proceed to "Separation and Recovery of DNA Fragments from an Agarose Gel".

\section{B. DNA Fragments Amplified by PCR}

Large amounts of DNA can be obtained by PCR. Many variations and applications of this technique, such as RTPCR (reverse transcription PCR), 5'-RACE (rapid amplification of 5 '-cDNA ends), and XL-PCR (extra long PCR), have been developed to serve various needs. A successful PCR amplification starts with the selection of appropriate primer pairs and then optimization of the PCR conditions (such as annealing temperature, extension time, and $\mathrm{Mg}^{++}$concentration). Several thermal stable enzymes such as Taq, Vent, pfu, and Tth polymerases, are available. General PCR references should be consulted to select the enzyme best suited to your needs $(17,18)$. After successful PCR amplification, proceed to the next stage to clone the amplified DNA product.

\section{Separation and Recovery of DNA Fragments from an Agarose Gel}

The desired DNA fragments from restriction digestion are separated from other DNA fragments by agarose gel electrophoresis and the desired bands are cut out and recovered. PCR products consisting of a single specific band amplified by Taq polymerase can be directly ligated to T-vectors. However, the removal of the impurities such as primers and trace amounts of nonspecific products by gel separation or the use of direct DNA clean-up systems increases the percentage of colonies containing the correct inserts. If you use a thermo-stable DNA polymerase which does not preferentially add a 3'-A at the ends of the PCR products, removal of that enzyme by either gel separation or use of a direct DNA clean-up system is essential. When two or more desired PCR products are amplified in the same PCR reaction, or when the nonspecific amplification products are abundant enough to be visualized on a gel, it is necessary to purify the desired DNA fragments by gel electrophoresis (to avoid screening the positive colonies later by more complicated hybridization procedures). Purify and recover the DNA from agarose gels as described in the "Separation and Recovery of T-vectors on an Agarose Gel" section of protocol 1. In addition, the concentration of the purified DNA is estimated as described in protocol 1. 


\section{A-tailing of the Purified DNA using Taq Polymerase} In the presence of all four dNTPs, Taq polymerase will first fill in the 3'-recessed bases of the DNA fragment with 5'overhangs and then preferentially add A's to the 3 '-ends. Alternatively, the Taq enzyme will add an A directly to the 3 '-ends of a blunt-ended DNA fragment. In the case of PCR products or blunt-ended fragments, only dATP is necessary in the incubation mixture. However, a mixture of dNTPs works well in all cases, since Taq polymerase preferentially adds an A to the 3'-ends in the presence of all four dNTPs.

Before starting this step, calculate the concentration of the DNA fragment needed in a $10 \mu$ ligation reaction to give a 1:2 molar ratio of the T-vector to the inserts. Since no more than $2 \mu \mathrm{l}$ of A-tailed DNA is used in the ligation reaction, the final concentration of the DNA fragment in the A-tailing reaction mixture should be adjusted so that the amount of DNA fragment required for ligation will be contained in a volume of $2 \mu \mathrm{l}$ or less. Should the DNA concentration be too low, you may concentrate the DNA before the Taq polymerase incubation step.

1. To a $0.5 \mathrm{ml}$ sterile centrifuge tube, add:

$\begin{array}{ll}\text { Purified DNA fragment } & 7.7 \mu \mathrm{l} \\ 10 \mathrm{X} \mathrm{PCR} \text { buffer, } \mathrm{Mg}^{++} \text {- free } & 1 \mu \mathrm{l} \\ 25 \mathrm{mM} \mathrm{MgCl}_{2} & 1 \mu \mathrm{l} \\ \text { dNTP mix, } 10 \mathrm{mM} \text { each } & 0.2 \mu \mathrm{l} \\ \text { Taq polymerase }(5 \mathrm{U} / \mu \mathrm{l}) & 0.1 \mu \mathrm{l}\end{array}$

Mix well and centrifuge briefly.

2. Incubate at $72^{\circ} \mathrm{C}$ for $25 \mathrm{~min}$, then transfer the tube to ice.

Ligation of the A-tailed DNA Fragment to the T-vector Usually $50-60 \mathrm{ng}$ of T-vector is enough for each ligation. A 1:2 molar ratio of T-vector to insert DNA is recommended, but do not add more than $2 \mu \mathrm{l}$ of A-tailed DNA solution in a $10 \mu$ ligation (see notes in previous section).

1. In a sterile $0.5 \mathrm{ml}$ microcentrifuge tube, add

$10 \mathrm{X}$ ligation buffer $1 \mu$

A-tailed DNA (from previous step) $\leq 2 \mu \mathrm{l}$

T-vector

$60 \mathrm{ng}$

T4 DNA ligase $(2-3 \mathrm{U} / \mu \mathrm{l}) \quad 1 \mu \mathrm{l}$

Sterile water to final total volume of $10 \mu \mathrm{l}$

Mix gently and centrifuge briefly.

2. Incubate at $14^{\circ} \mathrm{C}$ for $16 \mathrm{~h}$ or overnight. You may store the tube at $-20^{\circ} \mathrm{C}$ if you do not plan to transform the cells immediately.

Transformation of the Ligated Vector

LB agar plates with appropriate antibiotics (most commonly $100 \mu \mathrm{g} / \mathrm{ml}$ of ampicillin) should be available and warmed to room temperature. If a plasmid with blue/white color selection is used, the LB plates should be spread with 5bromo-4-chloro-3-indolyl- $\beta$-D-galactoside (X-Gal) and isopropylthio- $\beta$-D-galactoside (IPTG) before transformation. $\mathrm{A} 42^{\circ} \mathrm{C}$ water bath should be available for the transformation.

When a control ligation reaction with the T-vector alone is transformed, a considerable number of colonies may be obtained. When ligating inserts to the T-vectors, up to 90 $\%$ colonies should be positive. A successful ligation and transformation should yield hundreds of colonies. When few colonies are obtained, the ligase activity or the competency of the cells should be checked.

1. Thaw on ice one $50 \mu \mathrm{l}$ aliquot of appropriate frozen competent cells (for example, Top 10F') for each ligation reaction.

2. Add $2 \mu \mathrm{l}$ of $0.5 \mathrm{M} \beta$-mercaptoethanol to the competent cells and mix by stirring gently with the pipette tip.

3. Add $2 \mu \mathrm{l}$ of the ligation reaction to the competent cells, and mix gently by stirring with the pipette tip.

4. Incubate on ice for $30 \mathrm{~min}$.

5. Heat shock the cells for $30 \mathrm{~s}$ in the $42^{\circ} \mathrm{C}$ water bath, then immediately place the cells on ice for $2 \mathrm{~min}$.

6. Add $450 \mu \mathrm{l}$ of SOC medium to the transformed cell vial.

7. Shake the cells at $37^{\circ} \mathrm{C}$ for $45-60 \mathrm{~min}$ at $225 \mathrm{rpm}$ in a rotary shaking incubator.

8. Spread $100 \mu$ l of the transformed cells on each labeled LB-ampicillin plate. If plasmid with blue/white selection is used, the LB-plates should be spread with X-Gal and IPTG before spreading the cells.

9. Invert the plates and place them in a $37^{\circ} \mathrm{C}$ incubator overnight.

\section{Identification of Positive Colonies}

After transformation, the positive colonies may be identified either by restriction mapping of the miniprepared plasmids or screening by PCR. PCR screening can be carried out with primers that flank the vector cloning sites. In the case of the pBluescript plasmid, T3 and T7 primers may be used (19). The length of the amplified PCR product of a positive clone will be the size of the insert plus the bases flanking the two primers on the plasmid. This method is rapid, but may not work in some cases, especially when the insert is very large. Specific primers for the cloned insert may also be used as PCR screening primers. For screening by restriction mapping, plasmids are miniprepared, the insert is released by digestion with two unique restriction enzymes from the multiple cloning sites, and the insert size is confirmed by agarose gel electrophoresis. The orientation of the insert in the plasmid can also be determined by appropriate restriction digestion, in some cases. If needed, the orientation and identity of the clone may be further confirmed by sequencing. Because of the high cloning efficiency, in most cases only four to six colonies need to be screened.

\section{Screening by Restriction Mapping}

1. Randomly pick 4-6 colonies (in case of blue/white color selection, pick white colonies), and grow overnight at $37^{\circ} \mathrm{C}$ in $4 \mathrm{ml}$ of LB medium with 50 $\mu \mathrm{g} / \mathrm{ml}$ of ampicillin.

2. Pellet $2-3 \mathrm{ml}$ of the cells by centrifuging for $2 \mathrm{~min}$ at top speed in a microcentrifuge. Isolate plasmids using Wizard Minipreps DNA purification system. The remaining cells may be stored at $4^{\circ} \mathrm{C}$ for $1-2$ days. For long term storage, add glycerol to $15 \%$, and store at $-70^{\circ} \mathrm{C}$.

3. Isolate plasmid DNA and digest $10-50 \%$ of the total preparation with the appropriate restriction enzymes.

4. Run an agarose gel to determine which colonies have the correct insert size and/or orientation.

5. Confirm the clone by sequencing when necessary. 


\section{Notes}

The universal TA cloning procedure relies on the assumption that all DNA fragments can be easily converted to double stranded DNA with single 3'-A overhangs at each end, and thus the T-vector becomes a ready-for-ligation universal cloning vector. The T-vectors can be prepared in bulk and stored as aliquots at $-20^{\circ} \mathrm{C}$ for future use. Long term storage may decrease the cloning efficiency and increase the background. New batches of T-vectors may be prepared using either the terminal transferase or Taq polymerase methods. T-vectors prepared employing terminal transferase produce more consistent results than those prepared by Taq polymerase. TA cloning kits which are convenient and have a high cloning efficiency are commercially available. However, cost may be a factor to consider.

The insert DNA may be ligated to the T-vectors in either direction, and TA cloning is thus ideal when both orientations of the insert DNA in the plasmid are required. The orientation of the insert in the plasmid can be determined by sequencing, and in some cases, it can be simply determined by restriction mapping. Unidirectional TA cloning can be achieved by hemi-phosphorylation of one end and dephosphorylation of the other end of both the T-vectors and the insert (Figure 2). Thus, only ligation in the designated direction can form a cyclic plasmid (with two nicks) which can be efficiently transformed into competent cells. The other ligation products will be linear heterodimers which can not be efficiently transformed into host cells. Hemi-phosphorylated T-vectors may be prepared by the Taq polymerase method as illustrated in Figure 2. The terminal transferase method is not suitable for the preparation of the hemiphosphorylated T-vectors, because the presence of $3^{\prime}$-ddT at the terminus of one strand and the lack of a 5'- phosphate on the other strand will prevent the formation of transformable cyclic plasmids. To prepare the PCR product for directional TA cloning, a single phosphorylated PCR primer, which can be prepared employing T4 polynucleotide kinase, is used to generate a hemi-phosphorylated PCR product. For DNA generated by restriction digestion, the substrate is first digested with one enzyme, dephosphorylated with alkaline phosphatase, and then digested with the second enzyme (Figure 2; Note: The alkaline phosphatase must be inactivated before the second enzyme digestion). The rest of the procedures will be the same as for the bi-directional TA cloning protocols.

\section{References}

1. Ausubel,F.M., Brent, R., Kingston, R.E., Moore, D.D., Seidman, J.G., Smith, J.A. and Struhl, K. 1987. Current Protocols in Molecular Biology. John Wiley \& Sons, New York, NY.

2. Sambrook, J., Fritsch, E.F. and Maniatis, T. 1989. Molecular Cloning: A Laboratory Manual. Cold Spring Harbor Laboratory Press, Cold Spring Harbor, New York.

3. Rashtchian, A. 1995. Novel methods for cloning and engineering genes using the polymerase chain reaction. Current Opinion in Biotech. 6: 30-36.

4. Hsiao, K. 1993. Exonuclease III induced ligase-free directional subcloning of PCR products. Nucleic Acids Res. 21: 5528-5529.
5. Aslanidis, C. and de Jong, P.J. 1991. Ligationindependent cloning of PCR products (LIC-PCR). Nucleic Acids Res. 18: 6069-6074.

6. Kaluz, S. and Flint, A.P.F. 1994. Ligation-independent cloning of PCR products with primers containing nonbase residues. Nucleic Acids Res. 22: 4845.

7. Jung, V., Pestka, S.B. and Pestka, S. 1993. Cloning of polymerase chain reaction-generated DNA containing terminal restriction endonuclease recognition sites. Methods in Enzymology. 208: 357362.

8. Crowe, J.S., Cooper, H.J., Smith, M.A., Sims, M.J., Parker, D. and Gewert, D. 1991. Improved cloning efficiency of polymerase chain reaction (PCR) products after proteinase K digestion. Nucleic Acids Res. 19: 184.

9. Costa, G.L. and Weiner, M.P. 1994. Polishing with T4 or Pfu polymerase increases the efficiency of cloning of PCR fragments. Nucleic Acids Res. 22: 2423.

10. Holton, T. A., and Graham, M. W. 1991. A simple and efficient method for direct cloning of PCR products using ddT-tailed vectors. Nucleic Acids Res. 19: 1156.

11. Marchuk, D., Drumm, M., Saulino, A. and Collins, F. S. 1991. Construction of T- vectors, a rapid and general system for direct cloning of unmodified PCR products. Nucleic Acids Res. 19: 1154.

12. Mead, D.A., Pey, N.K., Herrnstadt, C., Marcil, R.A. and Smith, L.M. 1991. A universal method for the direct cloning of PCR amplified nucleic acid. Bio/Technology. 9: 657-663.

13. Clark, J. M. 1988. Novel non-templated nucleotide addition reactions catalyzed by procaryotic and eucaryotic DNA polymerases. Nucleic Acids Res. 16: 9677- 9686.

14. Hu, G. 1993. DNA polymerase-catalyzed addition of nontemplated extra nucleotides to the 3 ' end of a DNA fragment. DNA Cell Biol. 12: 763-770.

15. Zhou, M.Y., Clark, S.E. and Gomez-Sanchez, C.E. 1995. Universal cloning method by TA strategy. BioTechniques. 19:34-35.

16. Hadjeb, N. and Berkowitz, G.A. 1996. Preparation of T-overhang vectors with high PCR product cloning efficiency. BioTechniques. 20: 20-22.

17. Erlich, H.A. 1989. PCR Technology. Stockton Press, New York, NY.

18. Innis, M.A., Gelfand, D.H., Sninsky, J.J. and White, T.J. 1990. PCR Protocols: A guide to Methods and Applications. Academic Press, Inc., San Diego, CA.

19. Trower, M.K. and Elgar, G.S. 1994. PCR cloning using T-vectors. In: Methods in Molecular Biology, Vol.31: Protocols for Gene Analysis. A.J. Harwood, ed. Humana Press Inc., Totowa, NJ. 


\section{Further Reading}

Caister Academic Press is a leading academic publisher of advanced texts in microbiology, molecular biology and medical research. Full details of all our publications at caister.com

- MALDI-TOF Mass Spectrometry in Microbiology Edited by: M Kostrzewa, S Schubert (2016) www.caister.com/malditof

- Aspergillus and Penicillium in the Post-genomic Era Edited by: RP Vries, IB Gelber, MR Andersen (2016) www.caister.com/aspergillus2

- The Bacteriocins: Current Knowledge and Future Prospects Edited by: RL Dorit, SM Roy, MA Riley (2016)

www.caister.com/bacteriocins

- Omics in Plant Disease Resistance Edited by: V Bhadauria (2016) www.caister.com/opd

- Acidophiles: Life in Extremely Acidic Environments Edited by: R Quatrini, DB Johnson (2016) www.caister.com/acidophiles

- Climate Change and Microbial Ecology: Current Research and Future Trend

Edited by: J Marxsen (2016)

www.caister.com/climate

- Biofilms in Bioremediation: Current Research and Emerging Technologies

Edited by: G Lear (2016)

www.caister.com/biorem

- Microalgae: Current Research and Applications Edited by: MN Tsaloglou (2016) www.caister.com/microalgae

- Gas Plasma Sterilization in Microbiology: Theory, Applications, Pitfalls and New Perspectives Edited by: H Shintani, A Sakudo (2016) www.caister.com/gasplasma

- Virus Evolution: Current Research and Future Directions Edited by: SC Weaver, M Denison, M Roossinck, et al. (2016) www.caister.com/virusevol

- Arboviruses: Molecular Biology, Evolution and Control Edited by: N Vasilakis, DJ Gubler (2016) www.caister.com/arbo

- Shigella: Molecular and Cellular Biology Edited by: WD Picking, WL Picking (2016) www.caister.com/shigella

-Aquatic Biofilms: Ecology, Water Quality and Wastewater Treatment

Edited by: AM Romaní, H Guasch, MD Balaguer (2016)

www.caister.com/aquaticbiofilms

- Alphaviruses: Current Biology

Edited by: S Mahalingam, L Herrero, B Herring (2016)

www.caister.com/alpha

- Thermophilic Microorganisms

Edited by: F Li (2015)

www.caister.com/thermophile
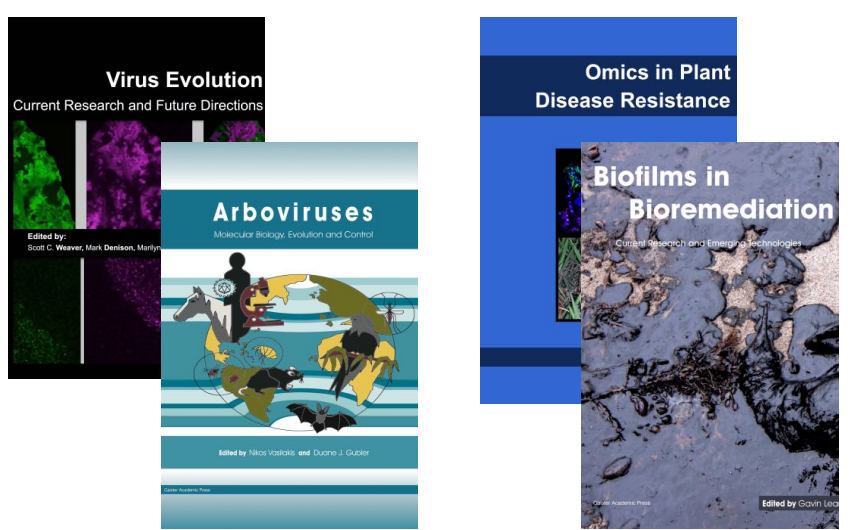
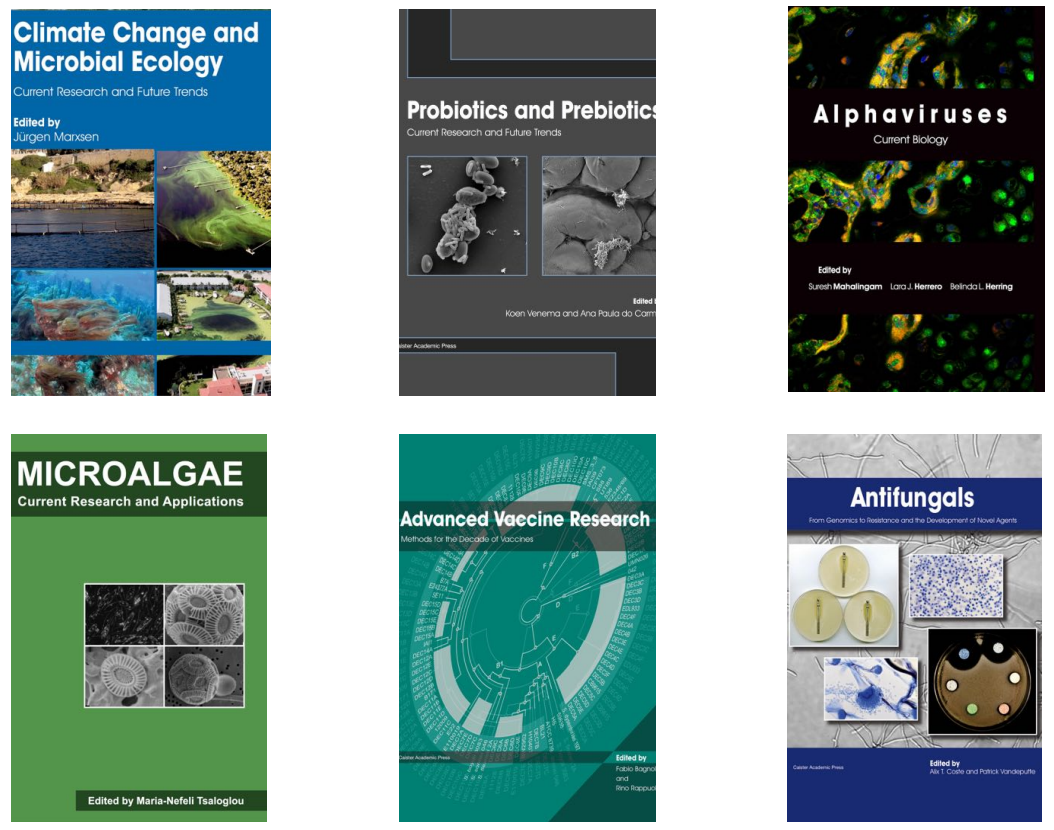

- Flow Cytometry in Microbiology: Technology and Applications Edited by: MG Wilkinson (2015) www.caister.com/flow

- Probiotics and Prebiotics: Current Research and Future Trends Edited by: K Venema, AP Carmo (2015) www.caister.com/probiotics

- Epigenetics: Current Research and Emerging Trends Edited by: BP Chadwick (2015) www.caister.com/epigenetics2015

- Corynebacterium glutamicum: From Systems Biology to Biotechnological Applications

Edited by: A Burkovski (2015)

www.caister.com/cory2

- Advanced Vaccine Research Methods for the Decade of Vaccines

Edited by: F Bagnoli, R Rappuoli (2015)

www.caister.com/vaccines

- Antifungals: From Genomics to Resistance and the Development of Novel Agents

Edited by: AT Coste, P Vandeputte (2015)

www.caister.com/antifungals

- Bacteria-Plant Interactions: Advanced Research and Future Trends Edited by: J Murillo, BA Vinatzer, RW Jackson, et al. (2015) www.caister.com/bacteria-plant

\section{- Aeromonas}

Edited by: J Graf (2015)

www.caister.com/aeromonas

- Antibiotics: Current Innovations and Future Trends

Edited by: S Sánchez, AL Demain (2015)

www.caister.com/antibiotics

- Leishmania: Current Biology and Contro Edited by: S Adak, R Datta (2015) www.caister.com/leish2

- Acanthamoeba: Biology and Pathogenesis (2nd edition) Author: NA Khan (2015)

www.caister.com/acanthamoeba2

- Microarrays: Current Technology, Innovations and Applications Edited by: Z He (2014)

www.caister.com/microarrays2

- Metagenomics of the Microbial Nitrogen Cycle: Theory, Methods and Applications

Edited by: D Marco (2014)

www.caister.com/n2 